\title{
Do talent management strategies influence the psychological contract within a diverse environment?
}

\begin{tabular}{|c|c|}
\hline \multicolumn{2}{|c|}{$\begin{array}{l}\text { Authors: } \\
\text { Paul Poisat }{ }^{1} \text { (D) } \\
\text { Michelle R. Mey } \\
\text { Gary Sharp }{ }^{3} \text { (D) }\end{array}$} \\
\hline \multicolumn{2}{|c|}{$\begin{array}{l}\text { Affiliations: } \\
{ }^{1} \text { Graduate School of Business, } \\
\text { Nelson Mandela University, } \\
\text { South Africa }\end{array}$} \\
\hline \multicolumn{2}{|c|}{$\begin{array}{l}{ }^{2} \text { School of Industrial } \\
\text { Psychology and Human } \\
\text { Resource Management, } \\
\text { Nelson Mandela University, } \\
\text { South Africa }\end{array}$} \\
\hline \multicolumn{2}{|c|}{$\begin{array}{l}{ }^{3} \text { Department of Statistics, } \\
\text { Nelson Mandela University, } \\
\text { South Africa }\end{array}$} \\
\hline \multicolumn{2}{|c|}{$\begin{array}{l}\text { Corresponding author: } \\
\text { Michelle Mey, } \\
\text { michelle.mey@mandela. } \\
\text { ac.za }\end{array}$} \\
\hline \multicolumn{2}{|c|}{$\begin{array}{l}\text { Dates: } \\
\text { Received: } 07 \text { Feb. } 2018 \\
\text { Accepted: } 24 \text { May } 2018 \\
\text { Published: } 30 \text { July } 2018\end{array}$} \\
\hline \multicolumn{2}{|c|}{$\begin{array}{l}\text { How to cite this article: } \\
\text { Poisat, P., Mey, M. R., \& } \\
\text { Sharp, G. (2018). Do talent } \\
\text { management strategies } \\
\text { influence the psychological } \\
\text { contract within a diverse } \\
\text { environment?. SA Journal } \\
\text { of Human Resource } \\
\text { Management/SA Tydskrif vir } \\
\text { Menslikehulpbronbestuur, } \\
\text { 16(0), a1044. https://doi. } \\
\text { org/10.4102/sajhrm. } \\
\text { v16i0.1044 }\end{array}$} \\
\hline \multicolumn{2}{|c|}{$\begin{array}{l}\text { Copyright: } \\
\text { (C) 2018. The Authors. } \\
\text { Licensee: AOSIS. This work } \\
\text { is licensed under the } \\
\text { Creative Commons } \\
\text { Attribution License. }\end{array}$} \\
\hline \multicolumn{2}{|l|}{ Read online: } \\
\hline 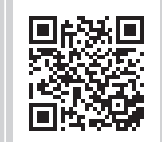 & $\begin{array}{l}\text { Scan this QR } \\
\text { code with your } \\
\text { smart phone or } \\
\text { mobile device } \\
\text { to read online. }\end{array}$ \\
\hline
\end{tabular}

Orientation: Even though globalisation has resulted in a more diverse workforce and working environment, talent management strategies have not evolved catering for the diversity experienced in organisations. It is assumed that talent management strategies developed on Western principles can be applied effectively to employees in emerging markets. However, the success of these strategies in creating a high-performance work culture is widely questioned.

Research purpose: This study aims to empirically determine the relationship between talent management strategies on the psychological contract, and whether this relationship influences employee retention within diverse working environments, which includes generational cohorts, gender and ethnicity.

Motivation for the study: As talent management strategies impact differently on the psychological contract of individuals across the generations, gender and ethnicity, it therefore implies that a fit for purpose talent management strategy must consider these variables. The reason for this study was to determine the influence of talent management strategies on the psychological contract and ultimately retention within the diverse environment of different generations, genders and ethnicity.

Research approach/design and method: A structured, closed-ended Likert-type validated questionnaire was distributed to employed persons of differing ethnicity, gender and generations and emanating from various professions within the private and public sector $(n=711)$. A quantitative survey design was used.

Main findings: A significant relationship between the work environment and the psychological contract on retention exists. On the contrary, no significant differences exist between growth and development and financial security. Unlike other research conducted on generational cohorts, this study revealed a strong correlation between talent management strategies and generational cohort preferences.

Practical/managerial implications: Talent management strategies need to be flexible and inclusive in terms of generational differences, including but not limited to ethnicity and gender. Human resource practitioners are made aware that the work environment impacts most significantly on the psychological contract and ultimately on retention.

Contribution/value-add: This study subscribes to the international literature and provides empirical evidence that demonstrates the importance of generational cohorts, gender and ethnicity when executing talent management strategies. This study empirically provides the basis for human resource (HR) practitioners to develop a customised generational talent management strategy to retain high performing individuals.

\section{Introduction}

Highly skilled employees are a scarce resource, particularly in developed countries. This is partly because of the ageing profile of Western and European workforces, as well as the consistent negative population growth in many established economies. In an increasingly globalised business world, multinational organisations must look to emerging markets to attract and retain talented individuals. This requires a fit for purpose talent management approach to attract, engage and retain employees in emerging markets as traditional approaches are based on Western principles and practices (Bluen, 2013). The Global Talent Competitiveness Index 2018 found that South Africa's ability to retain talent is poor as indicated by a ranking of 97 out of 119 countries (Knowledge Resources, 2018). An ageing workforce, coupled with diversity and generational considerations, requires that organisations reconsider their talent management strategies so as to address the varied expectations of employees pertaining to the work environment, 
financial security and growth and development (Knowledge Resources, 2017a; Thomsons Online Benefits, 2017).

Multiple authors have emphasised the universal need for talent management (Bluen, 2013; Böhmer \& Schinnenburg, 2016; Hafez, AbouelNeel \& Elsaid, 2017). In addition to being ranked 63rd overall on the Global Talent Competitiveness Index 2018, a lack of capacity, the risk of employee nonperformance and the extremely high costs associated with replacing staff are just a few of the reasons why talent management remains an increasingly important organisational consideration. Despite these realities, many organisations have failed to adapt to the challenges associated with increased globalisation and the resulting war for talent (Bluen, 2013; Knowledge Resources, 2017; Thunnissen, Boselie, \& Fruytier, 2013). Boudreau and Ramstad (2005) emphasise the significance of having a talent management focus in the organisation, whereas Lewis and Heckman (2006) point out the lack of research-based findings to acknowledge and understand the importance of talent management.

In addition, the importance of a psychological contract and its influence on retention needs to be considered. This is highlighted by Sonnenberg, Koene and Paauwe (2011) who support this and provide evidence that the more talent management practices an organisation employs, the higher employees perceived their psychological contract fulfilment, which results in higher levels of commitment and well-being and lower levels of intention to quit.

This article investigates the relationship between talent management strategies, the psychological contract and employee retention within the context of the various generational cohorts, gender and ethnicity. As such, this article contributes to the international literature by providing empirical evidence that a more specific and customised talent management approach is necessary while considering generational cohorts, gender and ethnicity.

\section{Talent management defined}

Although talent management is an integral part of organisational success, the concept itself lacks theoretical frameworks. Even though Collings and Mellahi (2009) are of the opinion that there is a lack of consistent definitions, they propose that talent management is seen as activities and practices that identify critical positions and develop high performers as well as establish 'differentiated human resource architecture to facilitate filling of these positions'. Typically, there are three mainstream interpretations of talent management. Talent management may firstly be described as a new term for common human resource practices; secondly, as an allusion of succession planning practices; and lastly, as referring to the general management of talented employees (Al Ariss, Cascio, \& Paauwe, 2014).

There is no one-size-fits-all solution to talent management. Generalisations made in terms of talent management strategies are complicated by diversity considerations, including the range of generations employed. Talent management strategies must be adjusted to accommodate the different values, characteristics, attitudes towards work and general world view of the different generational cohorts working together (Bluen, 2013; Festing \& Schäfer, 2014; Knowledge Resources, 2017b). Given the broad definitions of talent management, our approach is to view talent management strategies to include HR practices and policies pertaining to the work environment, financial security and growth and development. The operationalisation of these variables will follow.

\section{Operationalisation of variables}

An organisation is only as good as its people, and talent management should thus form the foundation on which organisations are built (Grobler et al., 2017). Figure 1 presents a conceptual model for this study. The model highlights talent management strategies relating to the working environment, financial stability, and growth and development as the independent variable, and retention as the dependent variable. Diversity considerations, including generational cohorts, gender and ethnicity, are presented as variables which were controlled for in this study, as they may or may not have affected the strength of the relationship between talent management and retention. The model further suggests that both organisational considerations (talent management strategies) and individual considerations (diversity issues) play a role in determining the nature of the psychological contract, which in itself may influence the dependent variable of retention.

\section{Work environment}

The work environment is vital to employee satisfaction. For the purpose of this study, work environment includes the conditions wherein an employee operates, their roles and responsibilities, whether sufficient authority is given to employees to make and implement decisions about their work and the nature of working relationships. One such working relationship is that between management and employees. This relationship needs to be one of trust, mutual respect and belief in employee capabilities._Changing ways of working necessitated by the knowledge-intensive nature of work as well as the continuously developing possibilities provided by information and communication technology have also inevitably changed the working environment.

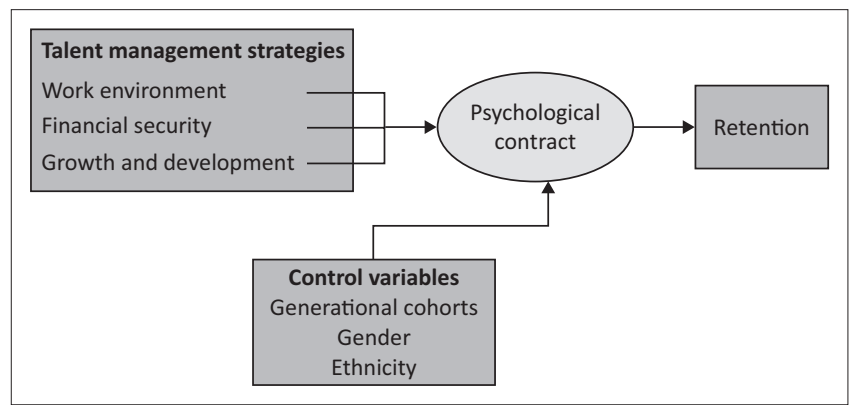

FIGURE 1: Conceptual model for the study. 
Several authors such as Bosch-Sijtsema, Fruchter, Vartiainen and Ruohomäki (2011); Gorgievski, Bakker and Schaufeli (2010); Peters, Poutsma, Van der Heijden, Bakker and Bruijn (2014) and Van der Voordt (2004) have explored these changing working practices. Flexible and mobile work practices have increased in popularity as they provide employees with more autonomy in deciding when, where and how their work gets done. Flexibility in work practices is especially important for females and ultimately leads to employee retention (Du Plessis \& Barkhuizen, 2015). There are also the preferences that the different generational cohorts bring to the work environment. Gursoy, Maier and Chi (2008) found that Baby Boomers have a high respect for authority and hierarchy in the workplace. Conversely, Generation Xers are seen as being more self-reliant, independent and sceptical of authority (Crumpacker \& Crumpacker, 2007). Millennials prefer more flexibility and time off work that will suit their lifestyle (Roy, 2008). These characteristics will, in turn, affect the preferred work environment of the different generations.

\section{Financial security}

Financial security as a variable is complex and comprises of financial and non-financial rewards (Bussin \& Van Rooy, 2014). Financial security is the individual's peace of mind that their income is sufficient to cover their expenses. Research in the South African context with regard to financial security and generational cohorts is inconclusive as the different generations place value on different aspects of financial security (Bussin \& Van Rooy, 2014; Masibigiri \& Nienaber, 2011; Moore \& Bussin, 2012). For the purpose of this study, factors contributing to financial security include work-life balance, recognition and achievements which, in turn, lead to job security.

\section{Growth and development}

The characteristics of a generation do not apply unilaterally to each member of a generational cohort as each individual is unique. Consideration must be given to the changing needs of employees which include freedom and flexibility in their job, opportunities to grow personally and professionally, as well as to experience fun at work. In this study, gender as a variable was controlled for as Clarke (2011) argues that development programmes should be specific to gender as this allows for discussion of challenges pertaining to that gender. D'Amato and Herzfeldt (2008) found that employees who have a higher organisational commitment and greater orientation are more likely to stay for the next 3 years. This finding highlights the importance of providing learning opportunities within the organisation to retain talent across generations.

\section{Psychological contract}

In his seminal work, Rousseau (1990) defines a psychological contract as the individual's beliefs in terms of reciprocal obligations between employees and employers. The contract emerges when a contribution is made, and thus, an obligation is created to provide future benefits or fulfilment of needs. This expected reciprocal obligation has an impact on employee performance beyond the levels expected in their formal contract (Ye, Cardon, \& Rivera, 2012). Differences in the interpretation of what constitutes a psychological contract between parties may be a challenge because of the contract being of an unwritten nature and may cause problems within the organisation (Ye et al., 2012). The employee evaluates these individual perceptions by comparing organisational experiences such as talent management practices to their own psychological contracts (Festing \& Schäfer, 2014).

When employers live up to the expectations of employees in terms of the psychological contract, employees are more likely to experience job satisfaction, demonstrate organisational commitment and eagerness to develop and learn within the organisation, and display willingness to contribute to organisational goals (Festing \& Schäfer, 2014). However, if they fail to meet employee expectations, they may be met with negative reactions such as reduced loyalty, reduced job performance and commitment, and the intention to quit (Festing \& Schäfer, 2014).

Crampton and Hodge (2007) postulate that generations develop different characteristics and work-related values and attitudes based on shared experiences in the formative years which contribute to shaping their lives. Research by Schambach (2001) suggests that the psychological contract may be perceived stronger by younger employees, as they feel the obligation of the reciprocal relationship more so than older employees, who have paid their dues to the organisation. A study on basic human value differences between generational cohorts indicated differences between Millennials and Generation Xers on 'openness to change' and 'self-enhancement' (Lyons, Duxbury, \& Higgins, 2007). Younger generations, early in their careers, may be prone to accept higher levels of risk (Johnson \& Lopes, 2008). The requirements of the psychological contract differ between individuals (Farndale, Pai, Sparrow, \& Scullion, 2014). This will result in different generations having varying needs and expectations in terms of the psychological contract ( $\mathrm{D}^{\prime}$ Amato \& Herzfeldt, 2008; Festing \& Schäfer, 2014).

The above discussion leads to the formulation of the following hypothesis:

H1: Talent management strategies with a positive influence on the psychological contract enhance retention.

\section{Retention}

Research results claim that $65 \%$ of black employees have changed jobs at least once within three years (Zulu \& Parumasur, 2009). Therefore, it is critical that organisations explore strategies aimed at enhancing employee retention. These include maintaining a work-life balance, and ways to increase job satisfaction and organisational commitment (Ilies, Wilson, \& Wagner, 2009; Qu \& Zhao, 2012). These strategies, however, need to be flexible when dealing with 
different generational groups. Baby Boomers seek power, influence and authority over others, seek out status symbols, seniority and experience, and value opportunities to mentor others (Close, 2015). Generation Xers value control over their lives and place an immense value on work-life balance (Close, 2015). Millennials desire career progression and advancement, and want opportunities for on-the-job education (Close, 2015). Millennials are attracted to work that is challenging, meaningful and flexible and offers career mobility (Close, 2015).

The above leads to the formulation of the following hypothesis:

H2: The more positively talent management strategies are experienced by the generational cohorts, the more positive the employees' experience of the psychological contract will be and, in turn, retention will be enhanced.

\section{Generational cohorts}

Generational differences may also influence the preferred methods of communication within the organisation. Baby Boomers prefer to communicate face to face during meetings rather than over the phone (Simons, 2009). Wagner (2007), however, found that Generation X and Millennials generally prefer email and text messages. This may cause intergenerational issues as using communications methods that are unfamiliar or undesirable to one group may cause discomfort and conflict.

Baby Boomers are seen as being willing to sacrifice their personal and professional lives to achieve success and financial security (Glass, 2007), whereas Generation Xers focus on balancing their personal and professional lives, resulting in the reputation of being the generation that 'work to live not live to work' (Simons, 2009). Atkinson (2008) found that although Millennials see money as important, they are more motivated to maintain a good work-life balance. Millennials want strong workplace relationships, a sense of purpose and a feeling that they are making a difference. Not meeting these needs may decrease job satisfaction which may negatively impact on job security, resulting in the departure of highly qualified personnel, and the costs associated with employee turnover and weaker growth prospects (Cheese, Thomas, \& Craig, 2008 as quoted in Kilfman, 2009).

Baby Boomers tend to be more established in their careers than Millennials and will thus not place the same value on opportunities for learning and development (Close, 2015). This is largely because of Millennials generally being in the early stages of their career and desiring on-the-job training (Carlson, 2015). Even though it is generally accepted that Baby Boomers may have more knowledge and experience within the organisation, it will still be expected that they should be challenged to develop new skills and refresh old ones.

Three main generations are identified in today's workforce, namely Baby Boomers (born between 1945 and 1965),
Generation X (1966-1977) and Millennials (1978-1990) (Bussin \& Van Rooy, 2014). Although the exact dates that must be met to fall into one of these categories vary and some overlap exists, these generational cohorts show distinct characteristics which play a role in terms of how they perform in the workforce.

Cohort theory argues that growing up around the same time and experiencing events such as natural disasters, politics, economic conditions and pop culture at about the same point in their development lead individuals within a particular generational cohort to develop similar values, attitudes, opinions, employment expectations and life experiences (CIPD, 2009; D'Amato \& Herzfeldt, 2008; Festing \& Schäfer, 2014; Leuty \& Hansen, 2011; Macky, Gardner, \& Forsyth, 2008; Mayhew, 2014).

The above leads to the formulation of the following hypothesis:

H3: The influence of talent management strategies on the psychological contract is perceived differently between the different generational cohorts.

\section{Ethnicity}

South Africa has a wide range of cultural and racial diversity, as well as a history of discrimination against individuals on this basis. Issues around marginalisation and exclusion are still prominent in the South African context. Typically, South African organisations comprise of a multitude of cultures and must therefore develop talent management strategies that take all of these cultural differences into account. This is confirmed by The Economist Intelligence Unit (2010) report and Knowledge Resources (2017b), which highlight some of these challenges such as cultural conflict between employees (50\%), problems understanding the local culture (47\%) and variations in working styles and norms of behaviour in the office $(42 \%)$. Statistics of South Africa reveals that the blacks comprise of $75 \%$ of the South African total employed population (Knowledge Resources, 2018). The above leads to the question as to how the nature of the psychological contract is perceived by different ethnic groups.

The above leads to the formulation of the following hypothesis:

H4: The influence of talent management strategies on the psychological contract is perceived differently among ethnic groups.

\section{Research methodology}

A quantitative approach was selected for this study as it is appropriate in studies that emphasise quantification in the collection and analysis of data, and which adopt a deductive approach placing emphasis on the testing of theories (Bryman \& Bell, 2014). 


\section{Development of the measuring instrument}

A structured, closed-ended, five-point Likert-type questionnaire comprising 33 items was used to collect the data. The independent variable, talent management (TM) strategies, varies vastly among organisations based on size, type of industry and geographical location (Lewis \& Heckman, 2006). In order to derive a standardised measure of TM, employees' perceptions of TM strategies were assessed based on the motivational aspects derived from the job characteristics approach first developed by Campion in 1988. Twenty items, derived from the motivational scale developed by Campion and McClelland (1991) were clustered into three subsections comprising work environment (WE), financial security (FS), and growth and development (GD). Coefficient alpha values for this study ranged from 0.793 (WE), 0.807 (FS) and 0.844 (GD) and compared favourably to Campion and McClelland's (1991) alpha values ranging from 0.81 to 0.94 (see Table 3).

Meyer and Allen's (1997) scale measuring employees' emotional attachment to, identification with, and involvement in the organisation served as proxy for measuring employees' psychological contract (PC). The moderating variable, psychological contract, comprised eight statements. The coefficient alpha for this study was 0.847 (PC) and it was compared favourably to the study of Meyer and Allen's (1997) validated scale ranging from 0.77 to 0.88 .

Retention, the dependent variable, was measured using Lee, Mitchell, Sablynski, Burton and Holtom's (2004) five-item intention to quit scale. The coefficient alpha for this scale was 0.859 (see Table 2). Literature indicates that behavioural intention is generally a good predictor of future behaviour (Armitage \& Connor, 2001). Furthermore, Griffeth, Hom and Gaertner (2000) have shown that turnover intention is a strong predictor of actual turnover. In addition, generational cohort, gender and ethnicity were controlled for in this study in order to determine their impact on the psychological contract and retention.

\section{Study population}

The target population of this study was employees across the various generational cohorts in South Africa within the private and/or public sector and at all organisational levels including managerial, non-managerial and support and/or administrative employees, and comprising different gender and ethnic groupings. For the purpose of this study, the generational cohorts referred to include Baby Boomers, Generation $X$ and Millennials as represented by the age categories presented in the discussion (refer to Table 1).

\section{Data collection}

The respondents were identified by means of the snowball convenience sampling technique. The questionnaire link was emailed to potential respondents, and a total of 711 useable questionnaires were returned.
TABLE 1: Demographic profile of respondents.

\begin{tabular}{llccc}
\hline Profile & Category & No. of respondents & Count & Percentage \\
\hline Gender & Female & 711 & 319 & 44.8 \\
& Male & - & 392 & 55.2 \\
Age profile & Baby Boomers & 711 & 155 & 21.8 \\
& Gen X & - & 281 & 39.5 \\
& Millennials & - & 275 & 38.7 \\
Ethnicity & African & 711 & 288 & 40.5 \\
& Mixed race and Asian & - & 207 & 29.1 \\
& White & - & 216 & 30.4 \\
Employment & Full-time & 711 & 643 & 90.4 \\
& Part-time & - & 68 & 9.6 \\
Employment sector & Private & 711 & 450 & 63.3 \\
& Public & - & 230 & 32.3 \\
& NGO & - & 17 & 2.4 \\
& Other & - & 14 & 2.0 \\
\hline
\end{tabular}

NGO, non-governmental organisations.

\section{Statistical analysis}

Structural equation modelling (SEM) was used to analyse the conceptual framework presented in Figure 2. The variables referred to in this study, work environment (WE), financial security (FS), growth and development (GD), psychological contract (PC) and retention (R), have been theoretically explored and operationalised using validated questionnaires. These variables were confirmed using exploratory factor analysis (EFA). Prior to the analyses being performed, the appropriateness of the data was assessed using Bartlett's Test of Sphericity and the Keiser-Meyer-Olkin measures of sampling adequacy (MSA), and ensuring an adequate sample size. Once deemed adequate, the analysis was performed. The SEM analysis was performed using a two-tiered modelbuilding approach. The confirmatory factor models were analysed to ensure suitable model fit prior to testing the structural models (Hair, Anderson, Tatham, \& Black, 1998). Each model was assessed using several goodness-of-fit indices. Once an appropriate model fit was obtained, the path estimates were interpreted and conclusions drawn (Byrne, 2010).

\section{Analysis of data}

The data were captured, cleaned and the biographical information analysed (Table 1). Of the 711 responses obtained, $44.8 \%$ were female and $55.2 \%$ male. The respondents were fairly evenly spread among the three generational age profiles: Baby Boomers (21.8\%), Generation X (39.5\%) and Millennials (38.7\%). The African ethnic group had the greatest frequency at $40.5 \%$. This was followed by the white ethnic group at $30.4 \%$ and the mixed race and Asian ethnic group at $29.1 \%$.

The Bartlett's Test of Sphericity and Kaiser-Meyer-Olkin MSA were calculated. The MSA value calculated was 0.915 , significantly higher than the minimum required value of 0.50 (Hair, Black, Babin, \& Anderson, 2014). The Bartlett's Test of Sphericity was found to be significant. This along with a sample size of 711 deemed the data appropriate for EFA.

The EFA was performed and the results were consistent with the theoretical variables. Within this study, the 


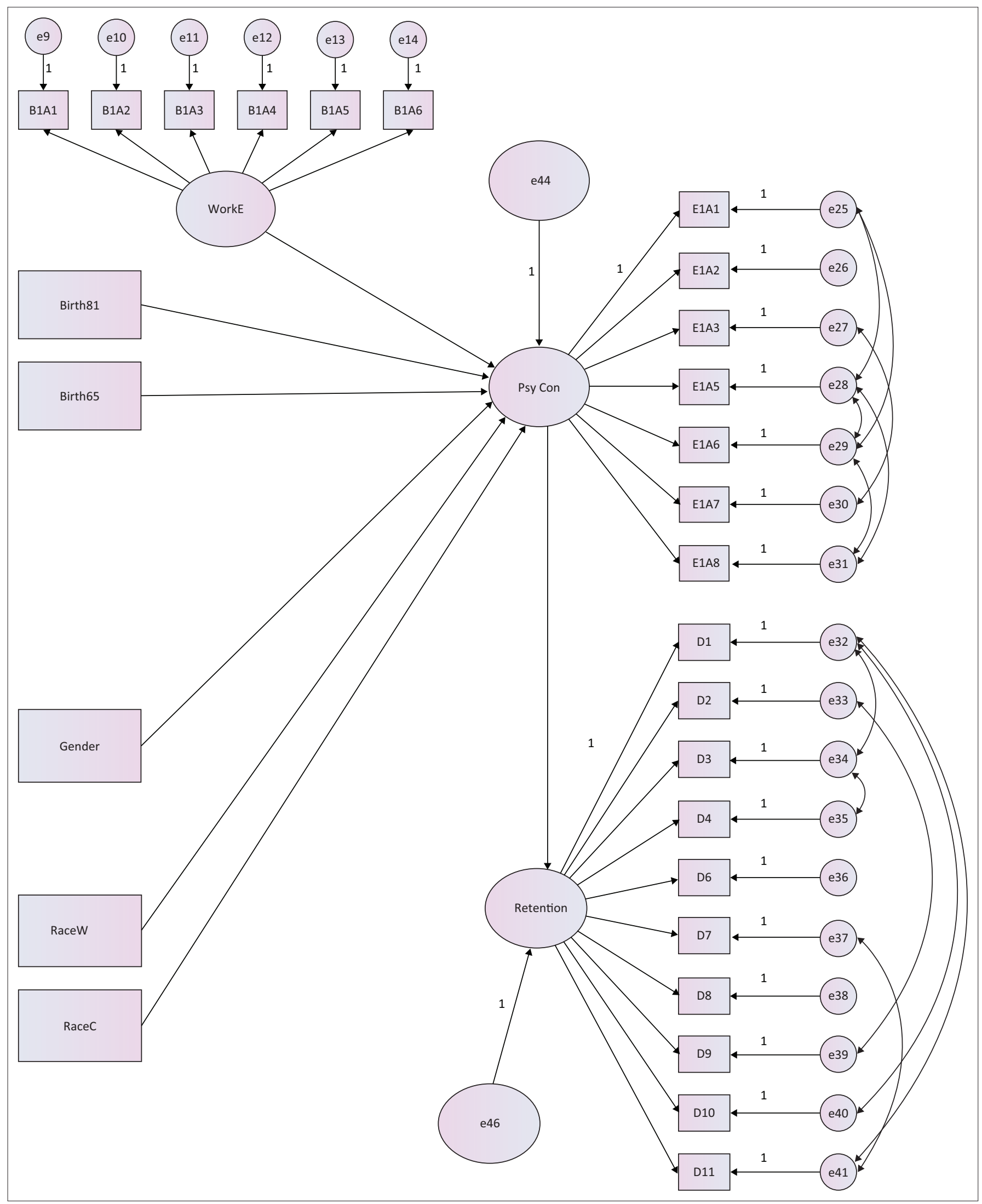

FIGURE 2: Final structural equation modelling model.

measurement model comprises of 33 items that explain the five constructs (WE, FS, GD, PC and R). Factor loadings of 0.45 were considered significant, which falls above the recommendation of 0.40 for sample sizes greater than 350 respondents (Hair, Black, Babin, \& Anderson, 2006). Several items did not load adequately and were therefore removed from the analysis. The EFA results provided evidence of the construct and discriminant validity of the measurement 
TABLE 2: Factor loadings of the variables.

\begin{tabular}{lcccc}
\hline Factor & $\begin{array}{c}\text { Item } \\
\text { indicator }\end{array}$ & $\begin{array}{c}\text { Standardised } \\
\text { loading }\end{array}$ & $\begin{array}{c}\text { Average variance } \\
\text { extracted }\end{array}$ & $\begin{array}{c}\text { Cronbach's } \\
\text { alpha }\end{array}$ \\
\hline Attraction work & B1A3 & 0.723 & - & 0.793 \\
environment (WE) & B1A2 & 0.647 & - & - \\
& B1A1 & 0.637 & - & - \\
& B1A6 & 0.595 & - & - \\
& B1A5 & 0.589 & - & - \\
Attraction financial & B1A4 & 0.564 & - & - \\
stability (FS) & B1A15 & 0.841 & - & - \\
& B1A9 & 0.800 & - & - \\
& B1A13 & 0.761 & - & - \\
Attraction growth & B1A10 & 0.581 & - & - \\
and development & B1A14 & 0.463 & - & - \\
(GD) & B1A16 & 0.814 & - & - \\
& B1A17 & 0.796 & - & - \\
& B1A20 & 0.680 & - & - \\
Psychological & B1A18 & 0.674 & - & - \\
contract (PC) & B1A7 & 0.605 & - & - \\
& E1A1 & -0.715 & - & - \\
& E1A2 & -0.694 & - & - \\
& E1A3 & -0.691 & - & - \\
& E1A5 & 0.723 & - & - \\
& E1A6 & 0.727 & - & - \\
Retention & E1A7 & -0.746 & - & - \\
\hline & E1A8 & 0.745 & - & - \\
\hline
\end{tabular}

TABLE 3: Regression weights.

\begin{tabular}{|c|c|c|c|c|}
\hline Regression & Estimate & SE & CR & $p$ \\
\hline Psychological contract $\leftarrow$ Work environment & 0.156 & 0.087 & 1.785 & 0.074 \\
\hline Psychological contract $\leftarrow$ Gender & -0.176 & 0.086 & -2.052 & 0.040 \\
\hline Psychological contract $\leftarrow$ Race - White & 0.555 & 0.093 & 5.943 & - \\
\hline Psychological contract $\leftarrow$ Race - Mixed race & 0.031 & 0.094 & 0.33 & 0.741 \\
\hline Psychological contract $\leftarrow$ Birth65 & -0.09 & 0.087 & -1.031 & 0.302 \\
\hline Psychological contract $\leftarrow$ Birth81 & -0.495 & 0.088 & -5.611 & - \\
\hline Retention $\quad \leftarrow$ Psychological contract & 0.832 & 0.045 & 18.339 & - \\
\hline
\end{tabular}

$\mathrm{SE}$, standard error; CR, capability ratio.

instrument. The internal reliability was assessed using Cronbach alphas and factor loadings, as seen in Table 2. A value of 0.70 or higher is considered reliable (Nunnally \& Bernstein, 1994).

As each construct had a Cronbach's alpha value of greater than 0.70, they were all deemed reliable. These constructs were then used in the SEM analysis. Each confirmatory factor model was analysed and assessed. The structural model based on the conceptual model in Figure 1 was analysed. The variables gender, generational cohort and ethnicity were then added to the structural model. The constructs GD and FS were removed from the analysis as the relationships between these constructs and PC were insignificant (Byrne, 2010). The resulting model can be found in Figure 2.

The model fit was assessed for the model in Figure 2 and indicates an average fit upon review of the indices. The $\mathrm{CMIN} / \mathrm{df}$ value, also called chi-square to $\mathrm{df}$ ratio, indicating an adequate model fit, of this sample size, is a value less than 5. The CMIN/df from the model indicates an appropriate model fit with a value of 4.935 . The root mean square error of approximation (RMSEA) value of 0.074 indicates a good model fit falling below the recommended value of 0.08 . The goodness-of-fit index (GFI) and comparative fit index (CFI) values were 0.863 and 0.841 , respectively, which are both close to the recommended value of 0.90 (Iacobucci, 2009). Therefore, the overall model fit indicates an average fit.
The unstandardised regression weights were then reviewed (Table 3). From the results, the relationship between WE and PC was significant at a $10 \%$ level, indicating a positive relationship. The relationship between gender and PC was significant at a $5 \%$ level, representing a negative relationship. The relationships of the mixed race ethnic grouping with PC, and Baby Boomers with PC, were found to be insignificant. The relationship between the white ethnic grouping and PC indicated a significant positive relationship, whereas the relationship between Millennials and PC indicated a significant negative relationship. This indicates that the white ethnic grouping tends to favour a higher level of PC, whereas the Millennials respondents did not favour a higher level of PC. The relationship between PC and retention indicated a significant positive relationship. This indicates that as the level of PC increases this leads to an increase in the level of retention.

From the results, it can be concluded that WE, white ethnic grouping and retention had a significant positive relationship with PC, whereas gender and Millennials had a significant negative relationship with $\mathrm{PC}$.

\section{Discussion and recommendations}

Strong support was found for H1 with the goodness-of-fit indices providing satisfactory measures for the structural model depicted in Figure 2. The structural model affirms that talent management strategies with a positive influence on the psychological contract enhance retention. This finding adds to psychological contract theory by isolating talent management strategies (TMS), more specifically WE, as having the most significant impact on psychological contract fulfilment within the context of gender, ethnic and generational cohorts. Our results show and affirm differences in perception among generational cohorts, thereby adding to the limited empirical evidence supporting generational differences. Understanding the nexus between the causal dynamics of TMS, its relationship to the psychological contract and the resultant impact on retention is fundamental to good management practice and creating an enabling work environment.

Millennials' perception of the influence of TMS on the psychological contract showed a significantly negative relationship $(-0.495, p=0.000)$. Considering that overall results confirmed a statistically positive relationship between TMS and the PC, it is significant to note that Millennials (38.7\% of the sample) perceived the influence to be negative. This finding supports earlier research outlining that workrelated attitudes are influenced more by generational experience (Twenge, Campbell, \& Hoffman, 2010). No significant statistical relationships were found for either Baby Boomers or Generation Xers. Therefore, $\mathrm{H} 2$ cannot be supported; however, Millennials' strong negative experience of TMS on the PC provides strong evidence of their dissatisfaction with TMS. Dissatisfaction with TMS may be as a result of the high premium they place on training, development and career mobility and also account for the difficulty experienced by organisations in retaining Millennial employees. The regression results for older 
generational cohorts (Baby Boomers and Generation X) were not significant and may be attributed to employees in these life stages being more settled in their careers and thus less likely to change jobs (Festing \& Schäfer, 2014). Nevertheless, findings amplify the need for TMS to be diversified in accordance with employees' life stages. TMS should include flexibility in working conditions (hours, off-site work), types of contracts (flexible work arrangements, gig-employees), remuneration and use of multimedia communication and be cognisant of the work-life balance of employees. Gender also showed a negative relationship with psychological contract $(-0.176, p=0.04)$, therefore reinforcing the need for a diversified, flexible TMS and supporting the notion that one size does indeed not fit all.

The findings support H3 that TMS influence employees' perceived psychological contract, with WE indicating a significant positive relationship with the psychological contract $(0.156, p=0.074)$ and is consistent with earlier research (Guest \& Conway, 2001; Sonnenberg et al., 2011). Based on the findings, WE takes precedence over financial security as well as growth and development that showed no significant relationship in influencing employees' psychological contracts. The conditions under which employees operate inclusive of roles and responsibilities, authority to implement decisions, feeling valued, participating in decision-making by offering ideas, and sharing information all contribute in creating an environment that positively influences employees' psychological contract. It is proffered that managers and HR practitioners carefully consider adopting strategies that create an inclusive climate conducive to participative decision-making based on openly sharing information within departmental and/or sectoral divisions. In addition, when allocating responsibility, the necessary authority should be clearly outlined and leadership should recognise employees for meeting agreed objectives.

Regression figures indicate that a strong positive relationship (0.555, $p=0.000$ ) exists for the white ethnic grouping's perception of the influence of TMS on the psychological contract. Conversely, no meaningful statistical relationships were found for any of the other ethnic groups. This variance in statistical findings among ethnic groups, axiomatically support H4 indicating that the influence of TMS on the psychological contract is perceived differently among ethnic groups. Consequently, it requires HR practitioners to vary and adjust their TMS in accordance with the preferences which may be expressed by different ethnic groupings. As such, constructs measuring cultural norms and customs will assist HR practitioners in mapping cross-cultural TMS. In addition to recognising the differences among generational cohorts, multinational global organisations operating in emerging markets have to provide locally relevant TMS. Strategies, other than those applied in developed (Western) economies and cognisant of the local culture, should be pursued. Our study showed that WE has a significant positive relationship with the PC but not so for the mixed race ethnic group and Baby Boomers. Therefore, HR practitioners and managers must understand the necessity of varying their leadership style, types of communication, level of inclusivity, types of rewards, involvement in decision-making and exercise of authority, which provide an enabling WE inclusive of ethnic and generational cohorts. Failing to adjust the work environment in line with cross-cultural demands may not create an environment conducive for the younger generation to contribute their creativity and productivity (Leung, Maddux, Galinsky \& Chiu, 2008). Moreover, the work environment may not engage the younger generation and add to lower levels of performance and impact upon retention (De Meuse \& Mlodzik, 2010). Specific acculturated strategies fall outside the ambit of this article; thus, further research is needed in understanding and translating local culture into TMS that stimulates a positive WE.

This article has sought to show that a relationship exists among TMS, the psychological contract, retention within the rich tapestry of generational cohorts, and gender and ethnic groupings. Sufficient statistical support for the aforementioned thesis has been provided against the back drop of generational cohort, gender and ethnic contextual complexities. Recommendations call for a cross-cultural and diversified talent management strategy that is flexible, inclusive, and sensitive to ethnic (cultural), gender and generational cohorts. The results of this study provide a basis for HR practitioners from which to develop a customised talent management strategy that is nuanced for the different generations, cultures and genders. More specifically, HRM practitioners should formulate specific inclusive WE strategies while considering industry specific needs.

\section{Limitations and implications for future research}

A limitation of the research was that the sample size was relatively small and that a larger sample would have allowed the authors to make more meaningful inferences on the data obtained.

The provision of development opportunities is likely to increase the organisational commitment of younger generations and to attract talented employees. Future research could investigate the developmental opportunities and corresponding perception of cohorts in emerging markets. Further enquiry is necessary into the cross-cultural dimensions of generational and ethnic cohorts that impact an enabling environment supporting creativity and engagement. Our research indicated that gender had a strong negative relationship between work environment and the psychological contract. As such, we believe further research is necessary to determine specific work environment requirements within a cross-cultural frame for female employees.

\section{Conclusion}

Retention of key employees is critical to the long-term success of an organisation. Retaining talented employees plays a vital role in customer satisfaction, product sales, satisfied co-workers and 
effective succession planning. To achieve the benefits of a competitive advantage and long-term success, talent management must become a critical strategic imperative. For this to be achieved, a clear and compelling strategy must be developed to attract, engage and retain staff across the different generations. By becoming more aware of the needs and preferences of their diverse workforce, organisations can develop suitable TMS. It is also important to determine whether strategies can be uniformly applied across the board or whether different strategies are required for various generations of employees comprising different gender and ethnic groupings.

\section{Acknowledgements Competing interests}

The authors declare that they have no financial or personal relationships that may have inappropriately influenced them in writing this article.

\section{Authors' contributions}

P.P. was the project leader and was responsible for the design of questionnaire and compilation of literature. M.R.M. was responsible for the design of questionnaire and compilation of literature. G.S. was responsible for the data analysis.

\section{References}

Al Ariss, A. A., Cascio, W. F., \& Paauwe, J. (2014). Talent management: Current theories and future research directions. Journal of World Business, 49, 173-179. https:// doi.org/10.1016/j.jwb.2013.11.001

Atkinson, P. (2008). Millennials: Researching the application of demographics to build customer relationships and HR strategy. Management Services, 52(1), 6-11.
Retrieved from http://connection.ebscohost.com/c/articles/31726638/millennialsRetrieved from http://connection.ebscohost.com/c/articles/31726638/millennials-
researching-application-demographics-build-customer-relationships-hr-strategy

Armitage, C. J., \& Conner, M. (2001), Efficacy of the theory of planned behaviour: A meta-analytic review. British Journal of Social Psychology, 40, 471-499. https:// doi.org/10.1348/014466601164939

Bluen, S. (2013). Talent management in emerging markets. Randburg, South Africa: Knowledge Resources Publishing.

Bosch-Sijtsema, P. M., Fruchter, R., Vartiainen, M., \& Ruohomäki, V. (2011). A framework to analyze knowledge work in distributed teams. Group \& Organization Management, 36(3), 275-307. https://doi.org/10.1177/1059601111403625

Böhmer, N., \& Schinnenburg, H. (2016). How gender and career concepts impact Global Talent Management. Employee Relations, 38(1), 73-93.

Boudreau, J. W., \& Ramstad, P. M. (2005). Talentship and the new paradigm for human resource management: From professional practices to strategic talent decision science. People and Strategy, 28(2), 17.

Bryman, A., \& Bell, E. (2014). Research methodology. Cape Town, South Africa: Oxford University Press.

Byrne, B. M. (2010). Structural equation modelling with AMOS: Basic concepts, applications and programming. New York: Routledge.

Bussin, M., \& Van Rooy, D. J. (2014). Total rewards strategy for a multi-generational workforce in a financial institution. SA Journal of Human Resource Management, 12(1), 1-11. https://doi.org/10.4102/sajhrm.v12i1.606

Campion, M. A., \& McClelland, C. L. (1991). Interdisciplinary examination of the costs and benefits of enlarged jobs: A job design quasi-experiment. Journal of Applied Psychology, 76920, 186-198. https://doi.org/10.1037/0021-9010.76.2.186

Carlson, C. (2015). Traditionalists, baby boomers, Generation X, Generation Y (and Generation Z) working together. What matters and how they learn, pp. 1-13. New York: Executive Office - United Nations Joint Staff Pension Fund.

Cheese, P., Thomas, R. J., \& Craig, E. (2008). Talent powered organization. Strategies for globalization, talent management and high performance. London, UK: Kogan Page Limited.

CIPD. (2009). Employer branding: Maintaining momentum in a recession: Chartered Institute of Personnel and Development (CIPD) guide. London: CIPD.

Clarke, M. (2011). Advancing women's careers through leadership development programs. Employee Relations, 33(5), 498-515. https://doi.org/10.1108/01425451111153871

Close, D. (2015). Generational motivation and preference for reward and recognition in a South African facilities management firm. Retrieved from http://uir.unisa. ac.za/bitstream/handle/10500/18558/dissertation_close_ds.pdf
Collings, D. G., \& Mellahi, K. (2009). Strategic talent management: A review and research agenda. Human Resource Management Review, 19(4), 304-313. https:// doi.org/10.1016/j.hrmr.2009.04.001

Crampton, S. M., \& Hodge, J. W. (2007). Generations in the workplace: Understanding age diversity. Business Review, 9(1), 16-22. Retrieved from https://www. researchgate.net/publication/291087554 Generations in the workplace Understanding_age_diversity

Crumpacker, M., \& Crumpacker, J. M. (2007). Succession planning and generational stereotypes: Should HR consider age-based values and attitudes a relevant factor or a passing fad? Public Personnel Management, 36(4), 349-369. Retrieved from http://journals.sagepub.com/doi/pdf/10.1177/009102600703600405

D’Amato, A., \& Herzfeldt, R. (2008). Learning orientation, organizational commitment and talent retention across generations. Journal of Managerial Psychology, 23(8), 929-953. https://doi.org/10.1108/02683940810904402

De Meuse, K. P., \& Mlodzik, K. J. (2010). A second look at generational differences in the workforce: Implications for HR and talent management. People \& Strategy, 33(2), 50-58.

Du Plessis, Y., \& Barkhuizen, N. (2015). Exploring the career path barriers of women professional engineers in a South African context. South African Journal of Labour Relations, 39(1), 38-57.

Farndale, E., Pai, A., Sparrow, P., \& Scullion, H. (2014). Balancing individual and organizational goals in global talent management: A mutual-benefits perspective. Journal of World Business, 49, 204-214. https://doi.org/10.1016/j.jwb.2013.11.004

Festing, M., \& Schäfer, L. (2014). Generational challenges to talent management: A framework for talent retention based on the psychological-contract perspective. Journal of World Business, 49, 262-271. https://doi.org/10.1016/j.jwb.2013.11.010

Glass, A. (2007). Understanding generational differences for competitive success. Industrial \& Commercial Training, 39(2), 98-103. https://doi.org/10.1108/ 00197850710732424

Gorgievski, M. J., Bakker, A. B., \& Schaufeli, W. B. (2010). Work engagement and Workaholism: Comparing the self-employed and salaried employees. The Journa of Positive Psychology, 5(1), 83-96. https://doi.org/10.1080/17439760903509606

Griffeth, R. W., Hom, P. W., \& Gaertner, S. (2000). A meta-analysis of antecedents and correlates of employee turnover: Update, moderator tests, and research implications for the next millennium. Journal of Management, 26, 463-488. https://doi.org/10.1177/014920630002600305

Grobler, P., Bothma, R., Brewster, C., Carey, L., Holland, P., \& Warnich, S. (2017) Contemporary issues in human resource management (4th edn.). Cape Town: Oxford University Press.

Guest, D., \& Conway, N. (2001). Public and private sector perspectives on the psychological contract: Results of the 2001 CIPD survey. Wimbledon, London: Chartered Institute of Personnel and Development.

Gursoy, D., Maier, T. A., \& Chi, C. G. (2008). Generational differences: An examination of work values and generational gaps in the hospitality workforce. International Journal of Hospitality Management, 27(3), 448-458. https://doi.org/10.1016/j. ijhm.2007.11.002

Hafez, E., AbouelNeel, R., \& Elsaid, E. (2017). An exploratory study on how talent management affects employee retention and job satisfaction for personnel administration in Ain Shams University Egypt. Journal of Management and Strategy, 8(4), 1. https://doi.org/10.5430/jms.v8n4p1

Hair, J. F., Jr., Anderson, R. E., Tatham, R. L., \& Black, W. C. (1998). Multivariate data analysis. Upper Saddle River, NJ: Prentice Hall.

Hair, J. F., Black, W. C., Babin, B. J., \& Anderson, R. E. (2006). Multivariate data analysis. Upper Saddle River, NJ: Prentice Hall.

Hair, J. F., Black, W. C., Babin, B. J., \& Anderson, R. E. (2014). Multivariate data analysis. New Jersey, United States: Pearson Education Limited.

lacobucci, D. (2009). Structural equations modeling: Fit Indices, sample size, and advanced topics. Journal of Consumer Psychology, 20, 90-98. https://doi. org/10.1016/j.jcps.2009.09.003

Ilies, R., Wilson, K. S., \& Wagner, D. T. (2009). The spillover of daily job satisfaction on the employees' family lives: The facilitating role of work-family integration. Academy of Management Journal, 52(1), 87-102. https://doi.org/10.5465/ AMJ.2009.36431938

Johnson, J. A., \& Lopes, J. (2008), The intergenerational workforce revisited. Organizational Development Journal, 26, 31-37.

Kilfman, S. (2009). Talent management in a multigenerational workforce. (2018). Masters, Tilburg University.

Knowledge Resources. (2017a). Human Capital and Labour Report: South Africa. South Africa.

Knowledge Resources. (2017b). On the Rise: Africa's Talent Mobility in the 21st Century Report. South Africa.

Knowledge Resources. (2018). Human Capital and Labour Report: South Africa. Randburg, South Africa: KR Publishing (PTY) LTD.

Lee, T. W., Mitchell, T. R., Sablynski, C. J., Burton, J. P., \& Holtom, B. C. (2004). The effects of job embeddedness on organisational citizenship, job performance, volitional absences and voluntary turnover. The Academy of Management Journal, 47(5), 711-722. Retrieved from http://www.jstor.org/stable/20159613

Leung, A. K. Y., Maddux, W. W., Galinsky, A. D., \& Chiu, C. Y. (2008). Multicultural experience enhances creativity: The when and how. American Psychologist, 63(3), 169. https://doi.org/10.1037/0003-066X.63.3.169

Leuty, M. E., \& Hansen, J. I. C. (2011). Evidence of construct validity for work values. Journal of Vocational Behavior, 79(2), 379-390. https://doi.org/10.1016/j. jvb.2011.04.008 
Lewis, R. E., \& Heckman, R. J. (2006). Talent management: A critical review. Human Resource Management Review, 16, 139-154. https://doi.org/10.1016/j. Resource Managem
hrmr.2006.03.001

Lyons, S. T., Duxbury, L., \& Higgins, C. (2007). An empirical assessment of generational differences in basic human values. Psychological reports, 101(2), 339-352. https://doi.org/10.2466/pro.101.2.339-352

Macky, K., Gardner, D., \& Forsyth, S. (2008). Generational differences at work: Introduction and overview. Journal of Managerial Psychology, 23(8), 857-861. https://doi.org/10.1108/02683940810904358

Masibigiri, V., \& Nienaber, H. (2011). Factors affecting the retention of Generation X public servants: An exploratory study. SA Journal of Human Resource Management, 9(1), 1-11. https://doi.org/10.4102/sajhrm.v27i4.318

Mayhew, D. R. (2014). Placing parties in American politics: Organization, electora settings, and government activity in the twentieth century. Princeton, NJ: Princeton University Press.

Meyer, J. P., \& Allen, N. J. (1997). Commitment in the workplace. Thousand Oakes, CA: Sage.

Moore, A., \& Bussin, M. (2012). Reward preferences for generations in selected Information and Communication Technology companies. SA Journal of Human Resource Management, 10(1), 1-9. https://doi.org/10.4102/sajhrm.v10i1.325

Nunnally, J. C., \& Bernstein, I. H. (1994). Psychometric theory. New York, NY: McGraw-Hill.

Peters, P., Poutsma, E., Van der Heijden, B. I., Bakker, A. B., \& Bruijn, T. D. (2014) Enjoying new ways to work: An HRM-process approach to study flow. Human Resource Management, 53(2), 271-290. https://doi.org/10.1002/hrm.21588

Qu, H., \& Zhao, X. (2012). Employees' work-family conflict moderating life and job satisfaction. Journal of Business Research, 65(1), 22-28. https://doi.org/10.1016/j. jbusres.2011.07.010

Rousseau, D. M. (1990). New hire perceptions of their own and their employer's obligations: A study of psychological contracts. Journal of Organizational Behavior 11(5), 389-400. https://doi.org/10.1002/job.4030110506

Roy, J. G. (2008). Ten tips for retaining the next generation. Utility Automation and Engineering $T \& D, 13(2)$, 8. Retrieved from $\mathrm{http}: / /$ connection.ebscohost.com/c/ articles/35636085/ten-tips-retaining-next-generation
Schambach, T. (2001). Age, motivation, and participation in professional development. Journal of Computer Information Systems, 41(4), 57-64.

Simons, A. (2009). Changing workplace demographics: $T+B+Y+X=$ opportunity. CPA Practice Management Forum, May, 15-23.

Sonnenberg, M., Koene, B., \& Paauwe, J. (2011). Balancing HRM: The psychological contract of employees: A multi-level study. Personnel Review, 40(6), 664-683. https://doi.org/10.1108/00483481111169625

The Economist Intelligence Unit. (2010). The Economist Intelligence Unit. Retrieved from http://www.eiu.com/home.aspx

Thunnissen, M., Boselie, P., \& Fruytier, B., 2013. Talent management and the relevance of context: Towards a pluralistic approach. Human Resource Management Review, 23, 326-336. https://doi.org/10.1016/j.hrmr.2013.05.004

Thomsons Online Benefits. (2017). Expectations vs reality: The widening gap in globa benefits. Retrieved from https://www.thomsons.com/resources/whitepapers/ the-widening-gap-between-expectations-and-reality/

Twenge, J. M., Campbell, S. M., Hoffman, B. J., \& Lance, C. E. (2010). Generational differences in work values: Leisure and extrinsic values increasing, social and intrinsic values decreasing. Journal of Management, 36(5), 1117-1142. https:// doi.org/10.1177/0149206309352246

Van Der Voordt, T. J. (2004). Productivity and employee satisfaction in flexible workplaces. Journal of Corporate Real Estate, 6(2), 133-148. https://doi.org/ $10.1108 / 14630010410812306$

Wagner, K. L. (2007). Filling the gap: The generation gap in the workplace creates challenges for managers wanting to build a team. Journal of Property Management, 72(5), 29-36.

Ye, J., Cardon, M. S., \& Rivera, E. (2012). A mutuality perspective of psychological contracts regarding career development and job security. Journal of Business Research, 65, 294-301. https://doi.org/10.1016/j.jbusres.2011.03.006

Zulu, P. S., \& Parumasur, S. B. (2009). Employee perceptions of the management of cultural diversity and workplace transformation. SA Journal of Industrial Psychology, 35(1), 49-57. https://doi.org/10.4102/sajip.v35i1.426 